\title{
DAMPAK PERUBAHAN IKLIM TERHADAP KESEHATAN
}

\author{
SUSILAWATI 1 \\ ${ }^{1}$ Magister Ilmu Lingkungan Program Pasca Sarjana Universitas Jambi \\ Email: susilawati@gmail.com
}

\begin{abstract}
ABSTRAK
Perubahan iklim dapat mempengaruhi kesehatan manusia dengan dua cara yaitu secara langsung dan tidak langsung yaitu mempengaruhi kesehatan manusia secara langsung berupa paparan langsung dari perubahan pola cuaca ( temperatur, curah hujan, kenaikan muka air laut, dan peningkatan frekuensi cuaca ekstrim). Kejadian cuaca ektrim dapat mengancam kesehatan manusia bahkan kematian. Selain itu mempengaruhi kesehatan manusia secara tidak langsung. Mekanisme yang terjadi adalah perubahan iklim mempengaruhi faktor lingkungan seperti perubahan kualitas lingkungan (kualitas iar,udara, dan makanan), penipisan lapisan ozon,penurunan sumber daya air, kehilangan fungsi ekosistem, dan degradasi lahan yang pada akhirnya faktorfaktor tersebut akan mempengaruhi kesehatan manusia. Dampak tidak langsunya berupa kematian dan kesakitan akibat penyakit terkait perubahan iklim dipicu oleh adanya perubahan suhu,pencemaran udara,penyakit bawaan air dan makanan, serta penyakit bawaan ventor dan hewan pengerat, Malnutrisi, dapat terjadi karena terganggunya sumber makanan dan panen. Dari uraian diatas maka saran yang dapat kami sampaikan adalah untuk memperkuat regulasi aturan yang meperhatikan kualitas lingkungan sehingga dampak lingkungan dan kesehatan dapat di minimalisasi bahkan di hilangkan, kolaborasi dan sinergitas sektor yang penting dalam mengatasi perubahan iklim. Untuk masyarakat : untuk selalu menjaga lingkungan, hemat pemakaian energi, mengurangi penggunaan kendaraan bermotor, mengelola sampah rumah tangga, dll
\end{abstract}

\section{Kata Kunci: Perubahan Iklim, Kesehatan}

\section{PENDAHULUAN}

Isu perubahan iklim sudah hangat dibicarakan mengingat dampaknya yang serius pada berbagai aspek kehidupan terutama kesehatan. Potensi negatif atau risiko perubahan iklim terhadap kesehatan telah dipandang sebagai tantangan global yang dapat mengancam penghidupan manusia (wilby et al.,2009 Barnett 2010).laporan IPCC kelima (AR-5) (IPCC 2014) menunjukan bahwa iklim global telah mengalami pemanasan yang signifikan. Data pengamatan menunjukan suhu permukaan rata-rata global meningkat sebesar $0,85^{\circ} \mathrm{C}$ dalam 130 tahun terakhir. Kenaikan suhu bumi tidak hanya berdampak pada naiknya temperatur buki tetapi juga mengubah sistem iklimyang mempengaruhi berbagai aspek pada alam dan kehidupan manusia salah satunya kesehatan manusia. Data dilapangan menunjukan kerentana dan risiko perubahan iklim global tidak hanya secara serius mempengaruhi aktivitas ekonomi, sosial, dan politik namun juga melibakan serangkaian masalah kesehatan yang parah (PCC,2007b;McMichael et al., 2003). Dalam beberapa dekade terakhir frekuensi kejadian penyakit semakin tinggi seperti DBD, Malaria diare. Dikutif dari Indo DATIN 2016 sejak tahun 1968 terjadi peningkatan kasus DBD dari 58 menjadi 126.675 kasus pada 2015. Sementara 
itu juga, terdapat peningkatan sebesar $85 \%$ kabupaten/kota terserang DBD. Salah satu bentuk triger penyakit ini adalah perubahan iklim.

Peningkatan penggunaan bahan bakar fosil dan perubahan penggunaan lahan menghasilkan dan meningkatkan jumlah gas rumah kaca ke atmosfir bumi. Gas rumah kaca ini antara lain karbon dioksida (CO2), Metana (CH4) dan Nitrogen dioksida (N2O), dan peningkatan gas-gas ini menyebabkan peningkatan jumlah panas yang tertahan di atmosfer bumi,panas dari matahari yang biasanya akan dipancarkan kembali ke angkasa. Peningkatan panas telah menyebabkan efek rumah kaca, yang mengakibatkan iklim berubah.

Perubahan iklim global disertai dengan peningkatan frekuensi dan intensitas gelombang panas ( heatwaves). Suhu yang terlalu sktrem dapat menyebabkan kematian. Diberbagai negara dengan suhu yang eksrem, tingkat kematian selama musim dingin lebih tinggi dibandingkan selama musim panas. Bahaya perubahan iklim di indonesia kedepan ditandai dengan (1) kenaikan temperatur, (2) perubahan pola curah hujan, (3) kenaikan muak air laut/SLR, (4) kenaikan frekuensi dan intensitas iklim ektrem.bahaya tersebut dapat berpengaruh terhadap jalur kontaminasi mikroba,transmisi dinamis, angroekosistem dan hidrologi serta sosial ekonomi dan demografiserta dapat meinmbulkan dampak terhadap kesehatan.

\section{PERUBAHAN IKLIM}

Perubahan iklim adalah perubahan iklim yang diakibatkan langsung atau tidak langsung oleh aktivitas manusia yang menyebabkan perubahan komposisi atmosfir secara global dan selain itu juga berupa perubahan variabilitas alamaiah yang teramati pada kurun waktu yang dapat dibandingkan.

Dampak perubahan iklim terhadap kesehatan dapat terjadi secara langsung maupun tidak langsung :

1. Mempengaruhi kesehatan manusia secara langsung berupa paparan langsung dari perubahan pola cuaca ( suhu, curah hujan,kelembaban, kenaikan muka air laut dan peningkatan frekuensi cuaca ekstrem).

2. Mempengaruhi kesehatan manusia secara tidak langsung. Mekanisme yang terjadi adalah perubahan iklim mempengaruhi faktor lingkungan seperti perubahan kualita lingkungan ( kualitas air,udara dan makanan),penipisan lapisan ozon,penurunan sumber daya air,kehilangan fungsi ekosistem, dan degradasi lahan yang pada akhirnya tersebut mempengaruhi kesehatan manusia.

Dampak kesehatan akibat perubahan iklim di antaranya dapat menimbukan polusi udara yang berpengaruh terhadap kesehatan (air pollution), penyakit yang berhubungan dengan air dan makanan (water and food borne diseases), penyakit yang berhubungan dengan fektor ( vektor borne diseases), malnutrisi,gangguan mental,heat stress.

Faktor Risiko kesehatan terhadap perubahan iklim terdiri dari :

1. Faktor Risiko penyakit tular Vektor ( Vektor borne disease) Akibat perubahan iklim

a. Faktor-faktor iklim berpengaruh terhadap risiko penularan penyakit tular vektor seperti DBD, Chikungunya, Malaria, Leptospirosis, Filariasis dan lain-lain 
b. Kelembaban,Curah hujan dan jumlah hari hujan mempunyai hubungan positif dengan kasus DBD. Semakin tinggi curah hujan dan hari hujan, breeding places semakin meluas keberadaannya, maka kasus DBD semakin meningkat. Kelembaban,curah hujan dan hari hujan mempengaruhi Umur nyamuk/vektor $<60 \%$ umur nyamuk pendek (potensial sebagai ventor makin menurun), curah hujan yang sedang tetapi waktunya panjang akan menambah breeding places sehingga berisiko meningkat populasi vektor,curah hujan yang tinggi dan terus menerus yang mengakibatkan banjir akan menyebabkan breeding places hanyut dan menyebabkan populasi berkurang tetapi banjir berpotensi terhadap frekuensi keterpaparan kencing tikus yang terinfeksi bakteri dan firus

c. Suhu mempunyai hubungan erat dengan siklus perkembangan nyamuk, dan berpengaruh langsung terhadap perkembangan parasit dalam tubuh vektor. Rata-rata suhu optimum untuk perkembangbiakan vektor berkisar antara $25-27^{\circ} \mathrm{C}$ memerlukan rata-rata selama 12 hari, pada suhu diatas suhu optimum ( $32-35^{\circ} \mathrm{C}$ (focks et al 1995 et al kemenkes 2012) siklus hidup untuk aedes menjadi lebih pendek (rata-rata 7 hari)potensinya lebih sering ukuran tubuh nyamuk lebih kecil dari ukuran normal sehingga pergerakan nyamuk menjadi lebih agresif. Perubahan tersebut menjadi risiko penularan 3 kali lipat lebih tinggi. Pada suhu ekstrim yaitu $10^{\circ} \mathrm{C}$ atau lebih dari $40^{\circ} \mathrm{C}$ perkembangan nyamuk akan terhenti (mati). Suhu berpengaruh terhadap pertumbuhan parasit/kuman dalam tubuh vektor, suhu kritis terendah siklus sporogoni pada plasmodium vivax adalah $16^{\circ} \mathrm{C}$,plasmodium falcifarum $19^{\circ} \mathrm{C}$ dan virus dengue $17^{\circ} \mathrm{C}$.

2. Faktor Risiko penyakit tular Air ( Water birne disease) akibat perubahan iklim

Suhu yang lebih panas berpengaruh pada produksi makanan dan ketersediaan air. Perubahan iklim mengakibatkan kekeringan serta banjir pada kondisi cuaca yang panas dimana terjadi pencairan es di kutub utara sehingga mempengaruhi kualitas,kuantitas dan aksesibilitas air minum/air bersih. Air merupakan kebutuhan dasar makhluk hidup, namun air yang disediakan untuk keperluan sehari-hari termasuk MCK juga dapat memberikan dampak yang merugikan manusia beserta lingkungannya. Ketidak cukupan kualitas,kuantitas dan aksesibilitas dapat membuka peluang munculnya penyakit bawaan air ini. Virus dan bakteri berkembang pesat dengan adalanya global warming sehingga menyebabkan penyakit diare meningkat.

3. Faktor risiko penyakit tular makanan dan gizi ( food borne disease and Nutrision) $\begin{array}{cccc}\text { Pangan } & \text { dan air } & \text { adalah } \\ \text { kebutuhan } & \text { dasar } & \text { makluk }\end{array}$ hidup.perubahan iklim berpengaruh pada produksi pangan dan ketersediaan air. Gagal panen dan kekeringan akibat perubahan iklim dapat mepengaruhi ketersediaan pangan di tingkat masyarakat. Sistim distribusi dan daya beli masyarakat sangat menentukan ketersediaan pangan di tingkat rumah 
tangga. Ketidak cukupan kualitas,kuantitas dan aksesibilitas dapat membuka peluang munculnya masalah gizi.

4. Faktor risiko penyakit tular udara ( Air borne disease )

Perubahan iklim diperkirakan dapat berkontribusi terhadap masalah kualitas udara (IPCC,2007 et al kemenkes 2012). Gangguan pernafasan mungkin memburuk oleh pemanasan yang diakibatkan peningkatan pada frekuensi smog event ( ozon tingkat dasar) dan polusi udara partikulat.

Ground level ozon dapat merusak jaringan paru, dan sangat berbahaya bagi penderita Asma dan penyakit paru kronis. Sinar matahari dan suhu tinggi, dikombinasikan dengan polutan lain seperti oksida nitrogen dan senyawa organik yang mudah menguap, dapat menyebabkan ozon tingkat dasar meningkat. Perubahan iklim dapat meningkatkan konsentrasi ozon tingkat dasar. Polutan lain yang menjadi perhatian adalah " partikel," juga di kenal sebagai partikel pencemar atau particulate matter (PM) materi partikulat adalah senyawa kompleks antara partikel yang sangat kecil dan tetesan air. Ketika dihirup partikel-partikel ini dapat mencapai daerah terdalam dari paru-paru.paparan dengan partikel pencemaran partikel juga merupakan penyebab utama penurunan daya pandang (kabut). Perubahan iklim secara tidak langsung dapat mempengaruhi konsentrasi pencemaran PM di udara dengan mempengaruhi sumber PM alami atau "biogeni," seperti kebakaran hutan dan debu dari tanah kering.

5. Faktor risiko penyakit tidak menular

Faktor risiko penyakit tidak menular adalah suatu kondisi secara potensial berbahaya dan dapat memicu terjadinya penyakit tidak menular pada seseorang atau kelompok tertentu. Menurunnya kualitas lingkungan akibat perubahan iklim menyebabkan tingginya tingkat polusi lingkungan,mengakibatkan berbagai penyakit tidak menular seperti kanker kulit,asma,penyakit yang disebabkan oleh gangguan imun, heat stroke dan lain-lain.

6. Faktor risiko perubahan iklim terhadap kejadian bencana

Terjadinya kenaikan suhu di bumi, yang mengakibatkan hilangnya keseimbangan dalam siklus bumi dan kenaikan suhu permukaan serta perubahan musim yang tidak dapat diprediksi.perubahan iklim berdampak pada terjadinya bencana alam dimanamana mulai dari badai topan, badai siklon tropis,banjir,endemis dan kekeringan berupa fenomena alam akibat pemanasan global. Bencana alam dapat mengakibatkan dampak yang merusak pada bidang ekonomi,sosial,kesehatan dan lingkungan

7. Faktor risiko perubahan iklim terhadap gangguan jiwa

Sebagian besar orang yang terpapar perubahan iklim termasuk bencana dapat beradaptasi dengan baik, namun sebagian yang lain akan mengalami stres, perubahan perilaku dan dapat timbul gangguan jiwa. 
Gangguan jiwa terbanyak yang
ditemukan saat bencana adalah
gangguan depresi,cemas,gangguan stres akut serta gangguan stres pasca trauma. Terjadi rata-rata peningkatan prevalensi (dalam 1 tahun) gangguan jiwa ringan-sedang ( depresi dan cemas ringan-sedang termasuk gangguan stres pascatrauma)menjadi sekitar 15-20\%, sedangkan akibat segera dari bencana meningkatkan gangguan jiwa ringansedang tersebut sebesar 5-10\%.

Risiko dan tingkat masalah kesehatan jiwa akibat perubahan iklim termasuk bencana ditentukan oleh besarnya derajat keterpaparan terhadap bencana tersebut ( faktor penentu) faktor-faktor kerentanan dan pelindung di populasi tersebut (faktor penentu), faktor kerentanan dan pelindung tersebut (biologis,sosial,faktor ekonomi dan pengalaman individu ), stresor individu (ancaman

kematian,kehilangan,kerusakan tempat tinggal dan lain-lain), dan juga stresor sekunder ( hilangnya pekerjaan, kekwatiran finansial,masalah keluarga dII)

\section{STRATEGI ADAPTASI SEKTOR KESEHATAN TERHADAP PERUBAHAN IKLIM}

Adaptasi perubahan iklim
adalah cara menyesuaikan yang
dilakukan secara spontan atau
terencana untuk memberikan reaksi
terhadap perubahan iklim yang diprediksi
atau yang sudah terjadi. Strategi
adaptasi sektor kesehatan terhadap
dampak perubahan iklim bertujuan untuk

menangani dampak buruk terhadap kesehatan akibat perubahan iklim. Strategi adaptasi kesehatan terhadap dampak perubahan iklim terdiri dari :

1. Sosialisasi dan advokasi adaptasi sektor kesehatan terhadap dampak perubahan iklim

2. Pemetaan populasi dan daerah rentan dampak perubahan iklim (pengumpulan data penyebaran penyakit,perubahan/variabel iklim, faktor risiko lingkungan,faktor risiko lingkungan,faktor risiko sosial, ekonomi dan geografi), analisis penyebaran penyakit,analisis perubahan variabel iklim, analisis faktor risiko lingkungan, analisis faktor risiko sosial, ekonomi dan demografi, analisis korelasi variabel iklim dan kesehatan.

3. Peningkatan sistim tanggap perubahan iklim sektor kesehatan
a. Kajian dan penelitian dampak perubahan iklim sektor kesehatan
b. Penguatan sistim kewaspadaan dini dampak perubahan iklim

c. Pengembangan strategi adaptasi spesifik lokal sesuai dengan dampak yang muncul
d. Pengembangan teknologi tempat guna.

4. Peraturan perundang-undangan

5. Peningkatan keterjangkauan pelayanan kesehatan, khususnya daerah rentan perubahan iklim

a. Pengembangan sarana dan prasarana pelayanan 
kesehatan yang disesuaikan dengan populasi dan daerah rentan perubahan iklim

b. Meningkatkan akses pelayanan kesehatan

6. Peningkatan kapasitas sumber daya manusia bidang kesehatan

7. Peningkatan pengendalian dan pencegahan penyakit akibat dampak perubahan iklim
a. Penguatan kesehatan lingkungan
b. Pengendalian faktor risiko penyakit
c. Penemuan penderita dan pengobatan
d. Pengendalian vektor secara terpadu
e. Penanggulangan bencana

8. Peningkatan kemitraan pembentukan kelompok kerja )

9. Peningkatan pemberdayaan masyarakat dalam adaptasi perubahan iklim sesuai kondisi setempat.
a. Pemberdayaan individu
b. Pemberdayaan keluarga
c. Pemberdayaan kelompok/masyarakat umum

10. Peningkatan surveilans dan sistem informasi
a. Pengumpulan dan analisis data penyakit,faktor risiko lingkungan,perilaku, dan iklim
b. Desiminasi informasi
c. Rencana tidak lanjut.

\section{KESIMPULAN}

Perubahan iklim dapat
mempengaruhi kesehatan manusia

dengan dua cara yaitu secara langsung dan tidak langsung yaitu:

1. Mempengaruhi kesehatan manusia secara langsung berupa paparan langsung dari perubahan pola cuaca ( temperatur, curah hujan, kenaikan muka air laut, dan peningkatan frekuensi cuaca ekstrim). Kejadian cuaca ektrim dapat mengancam kesehatan manusia bahkan kematian

2. Mempengaruhi kesehatan manusia secara tidak langsung. Mekanisme yang terjadi adalah perubahan iklim mempengaruhi faktor lingkungan seperti perubahan kualitas lingkungan (kualitas iar,udara, dan makanan), penipisan lapisan ozon,penurunan sumber daya air, kehilangan fungsi ekosistem, dan degradasi lahan yang pada akhirnya faktor-faktor tersebut akan mempengaruhi kesehatan manusia. Dampak tidak langsunya berupa

a. Kematian dan kesakitan akibat penyakit terkait perubahan iklim dipicu oleh adanya perubahan suhu,pencemaran udara,penyakit bawaan air dan makanan, serta penyakit bawaan ventor dan hewan pengerat.

b. Malnutrisi, dapat terjadi karena terganggunya sumber makanan dan panen.

Dari uraian diatas maka saran yang dapat kami sampaikan adalah :

1. Kepada Pemerintah : untuk memperkuat regulasi aturan yang meperhatikan kualitas lingkungan sehingga dampak lingkungan dan kesehatan dapat di minimalisasi 
bahkan di hilangkan, kolaborasi dan sinergitas sektor yang penting dalam mengatasi perubahan iklim.

2. Untuk masyarakat : untuk selalu menjaga lingkungan, hemat pemakaian energi, mengurangi penggunaan kendaraan bermotor, mengelola sampah rumah tangga, dll.

\section{REFERENSI}

1. Kementerian kesehatan RI,2011." Strategi Adaptasi Sektor Kesehatan terhadap Dampak Perubahan Iklim". Jakarta. 2011

2. Kementerian Kesehatan RI,2012."Pedoman Identifikasi faktor Risiko Kesehatan akibat Perubahan Iklim". Jakarta 2012.

3. Kementerian Lingkungan Hidup dan Kehutanan RI,2016."Pedoman Penyusunan Aksi Adaptasi Perubahan Iklim.Jakarta.2016

4. Bappenas,2010." Indonesia Climate Change Sektoral Roadmap (ICCSR) Sektor Kesehatan. Jakarta.2010

5. JURNAL KESEHATAN MASYARAKAT (e-Journal)Volume 4, Nomor 5, Oktober 2016 (ISSN: 23563346)http://ejournal-s1.undip.ac.id/index.php/jkm di akses tanggal 20 September 2019 pukul $21.00 \mathrm{Wlb}$

6. Nadia Shabrina,https://www.academia.edu/9672128/makalah_perubahan_iklim diakses tanggal 20 September 2019 pukul 21.00 Wib.

7. Sri Gusni Febriasari,FKM UI,2011, Perubahan Iklim dengan Kejadian Penyakit Demam Berdarah Dengue (DBD) di Kota Administasi Jakarta Timur 2000-2009,di akses tanggal 11 september 2019 pukul 11.35 Wib. 